Institute of $\mathbf{F}_{\text {ood and }} \mathbf{A}_{\text {gricultural }} \mathbf{S}_{\text {ciences }}$

\title{
Banded Cucumber Beetle, Diabrotica balteata LeConte (Insecta: Coleoptera: Chrysomelidae) ${ }^{1}$
}

John L. Capinera²

\section{Introduction and Distribution}

The banded cucumber beetle is basically a tropical insect, and until the early 1900s its distribution in the United States was limited to southern Arizona and Texas (Saba 1970), and south through Mexico and Central America (Krysan 1986). It has since expanded its range throughout the southern United States from North Carolina to southern California, though its intolerance to freezing temperatures probably limits its northward distribution to its current status. Within Florida it is most abundant in the organic soils near Lake Okechobee, though it occurs throughout the state, where it is known as a vegetable pest.

\section{Life Cycle and Description}

The banded cucumber beetle does not enter diapause (Saba 1970). It remains active as long as the weather remains favorable, with up to six to seven generations per year reported in Louisiana (Pitre and Kantack 1962) and Texas. Under optimal conditions a life cycle can be completed in 45 days.
Egg

The eggs are yellow in color, oval in form, and measure about $0.6 \mathrm{~mm}$ in length and $0.35 \mathrm{~mm}$ in width. They are deposited in cracks in the soil, and require five to nine days to hatch (Marsh 1912).

\section{Larva}

The three instars have mean head capsule widths measuring about $0.24,0.35$, and $0.51 \mathrm{~mm}$, respectively. The body length during these instars is reported to be about $2.3,4.5$, and $8.9 \mathrm{~mm}$. Larval color is somewhat variable; initially it is white, but may also take on a pale yellow color depending on the food source. Development time is temperature dependent, but the range is about 4-8, 3-11, and 4-15 days for instars 1 to 3 , respectively. Total larval development time is usually 11 to 17 days.

\section{Pupa}

Pupation occurs in the soil, with a duration of four to six days.

1. This document is EENY-093, one of a series of Featured Creatures from the Entomology and Nematology Department, Florida Cooperative Extension Service, Institute of Food and Agricultural Sciences, University of Florida. Published: July 1999. This document is also available on Featured Creatures Website at http://creatures.ifas.ufl.edu. Please visit the EDIS Website at http://edis.ifas.ufl.edu. Additional information on these organisms, including many color photographs, is available at the Entomology and Nematology Department WWW site at http://entnemdept.ifas.ufl.edu/.

2. John L. Capinera, professor/chairman, Entomology and Nematology Department, Institute of Food and Agricultural Sciences, University of Florida, Gainesville, FL, 32611.

The Institute of Food and Agricultural Sciences is an equal opportunity/affirmative action employer authorized to provide research, educational information and other services only to individuals and institutions that function without regard to race, color, sex, age, handicap, or national origin. For information on obtaining other extension publications, contact your county Cooperative Extension Service office. Florida Cooperative Extension Service/Institute of Food and Agricultural Sciences/University of Florida/Christine Taylor Waddill, Dean. 


\section{Adult}

Adults are 5 to $6 \mathrm{~mm}$ in length, greenish yellow in color with a red head and black thorax. Usually there are three transverse bands across the elytra, green in color but sometimes with a bluish tint, and a thin green band running down the center of the insect's back. The banding pattern is variable, and sometimes almost absent (Chittenden 1912).

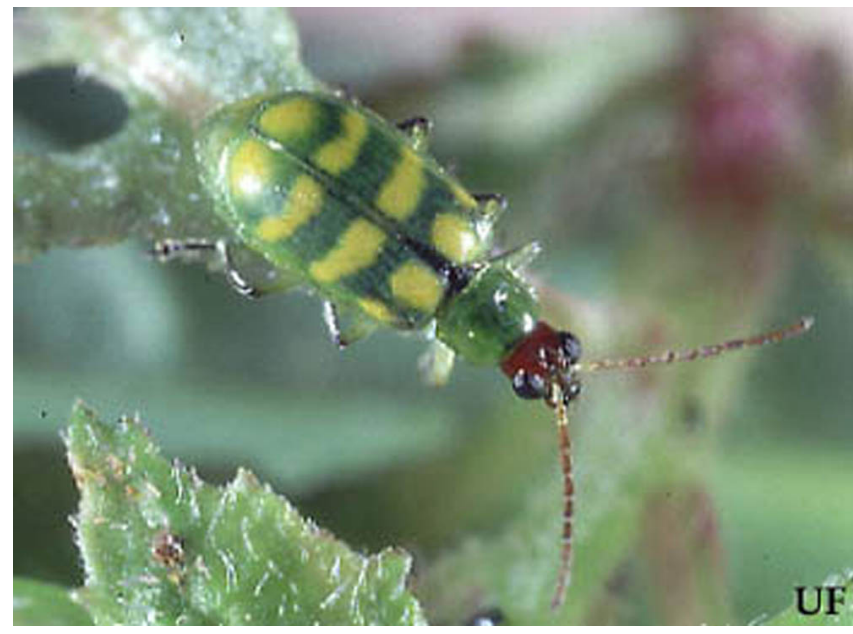

Figure 1. Adult banded cucumber beetle, Diabrotica balteata LeConte. Credits: John L. Capinera, University of Florida

Copulation occurs about six days after adult emergence, with egg deposition beginning about 16 days later. Oviposition takes place at two to three day intervals for two to eight weeks. Females normally deposit two to15 egg clusters of up to 100 eggs each. A total of 850 eggs may be produced by a female. Adult longevity is 17 to 44 days, but averages 26 days.

\section{Host Plants}

Adults feed on a wide range of plants, but seem to prefer plants from the family Cucurbitaceae, Rosaceae, Leguminoseae, and Crucifereae (Saba 1970). Vegetable crops damaged include cucumber, squash, beet, bean, pea, sweet potato, okra, corn, lettuce, onion, and various cabbages. Bean and soybean are especially favored (Chittenden 1912, Saba 1970).

\section{Damage}

The banded cucumber beetle is nearly omnivorous, and in addition to numerous plants being attacked, all parts of the plant are injured. Damage may occur to foliage, blossoms, silk, kernels, the plant crown, and roots. Larvae feed only on the roots. The most frequent forms of serious injury are defoliation by adults and root feeding on plant seedlings by larvae. Some of the most serious injury results from larval feeding on sweet potato roots. Banded cucumber beetle is known as a vector of virus diseases in beans, and larval feeding might increase the incidence and severity of Fusarium wilt.

\section{Natural Enemies}

Except for nematodes, the natural enemies of banded cucumber beetle are poorly known. The mermithid nematode Filipjevimermis leipsandra affects this species, and natural infection levels in South Carolina were reported to be in the range of 20 to 40 percent from May through October. Ants have been shown to be important egg predators in the tropics, and likely are important elsewhere.

\section{Management}

Insecticides are sometimes used to prevent damage to roots by larvae. Most often, granular insecticides are applied in a band over the row, either at time of planting or soon thereafter. Foliar insecticides are sometimes needed to prevent excessive damage to seedlings, but adults are rarely abundant enough to warrant control on large plants.

For specific insecticide recommendations see:

Insect Management Guide for Vegetables

Insect Management Guide for Field Crops

Two nematodes have been well studied for suppression of banded cucumber beetle: the mermithid Filipjevimermis leipsandra and the heterorhabditid Heterorhabditis heliothidis. Creighton and Fassuliotis (1983) induced high levels of parasitism in banded cucumber beetle larvae by $F$. leipsandra with application of nematode eggs to field microplots, but the nematode is not available commercially. Heterorhabditis heliothidis was found 
naturally parasitizing banded cucumber beetle (Creighton and Fassuliotis 1985), and effectively reduced beetle larval numbers in pot trials. Although H. heliothidis is not available commercially, the related Steinernema nematodes are effective under experimental conditions and are readily available.

The wide host range of this insect, which includes many weed species, suggests that clean cultivation or some other form of weed control would be valuable in reducing damage to seedlings. Adults can be kept from attacking seedlings through use of screening or row covers.

Cultivars of sweet potato partially resistant to cucumber beetle injury are known (Schalk and Creighton 1989), but this information seems to be lacking for other crops.

\section{Selected References}

Chittenden, F.H. 1912. Notes on the cucumber beetles. USDA Bur. Entomol. Bull. 82:67-75.

Creighton, C.S. and F. Fassuliotis. 1983. Infectivity and suppression of the banded cucumber beetle (Coleoptera: Chrysomelidae) by the mermithid nematode Filipjevimermis leipsandra (Mermithida: Mermithidae). J. Econ. Entomol. 76:615-618.

Creighton, C.S. and F. Fassuliotis. 1985. Heterorhabditis sp. (Nematoda: Heterorhabditidae): a nematode isolated from the banded cucumber beetle Diabrotica balteata. J. Nematol. 17:150-153.

Krysan, J.L. 1986. Introduction: biology, distribution, and identification of pest Diabrotica. Pages 1-23 in J.L. Krysan and T.A. Miller (eds.). Methods for the Study of Pest Diabrotica. Springer-Verlag, New York.

Marsh, H.O. 1912. Biologic notes on some species of Diabrotica in southern Texas. USDA Bur. Entomol. Bull. 82:76-84.

Pitre Jr., H. N. and E.J. Kantack. 1962. Biology of the banded cucumber beetle, Diabrotica balteata, in Louisiana. J. Econ. Entomol. 55:904-906.

Saba, F. 1970. Host plant spectrum and temperature limitations of Diabrotica balteata. Can. Entomol. 102:684-691.
Schalk, J. M. and C.S. Creighton. 1989.

Influence of sweet potato cultivars in combination with a biological control agent (Nematoda: Heterorhabditis heliothidis) on larval development of the banded cucumber beetle (Coleoptera: Chrysomelidae). Environ. Entomol. 18:897-899. 